\title{
GREEN ALGAE CHLORELLA VULGARIS CULTIVATION IN MUNICIPAL WASTEWATER AND BIOMASS COMPOSITION
}

\author{
Petras VENCKUS ${ }^{a}$ Jolanta KOSTKEVIČIENÉ ${ }^{a}$, Vida BENDIKIENÉ ${ }^{b}$ \\ ${ }^{a}$ Department of Botany and Genetics, Faculty of Natural Sciences, Vilnius University, \\ M. K. Ciurlionio 21/27, LT-03101 Vilnius, Lithuania \\ ${ }^{b}$ Department of Biochemistry and Molecular Biology, Faculty of Natural Sciences, Vilnius University, \\ M. K. Ciurlionio 21/27, LT-03101 Vilnius, Lithuania
}

Submitted 16 Nov. 2015; accepted 30 Sep. 2016

\begin{abstract}
This paper deals with the accumulation of lipids, carbohydrates and proteins in the biomass of the green algae Chlorella vulgaris that is cultivated in the municipal wastewater of Vilnius City. The growth rate of the culture on different chemical compositions of media was investigated. Dependence of lipid, carbohydrate and protein content on total phosphorus and nitrogen initial concentrations in wastewater and removal of nutrients was investigated. Data showed that the higher amount of total nitrogen is the main factor leading to a higher rate of biomass increase. The study showed that Chlorella vulgaris is capable of very efficient nutrient removal from wastewater (up to $86 \%$ of total nitrogen and $87 \%$ phosphorus was removed). Data showed that there is strong correlation between the initial concentration of nitrogen, and in some cases phosphorus, in the media and content of proteins and carbohydrates in the biomass. A higher amount of nitrogen in the starting media leads to a higher amount of proteins and a lower amount of carbohydrate in the biomass. There was no correlation found between the initial nitrogen or phosphorus concentration in the media and content of lipids in the biomass.
\end{abstract}

Keywords: Chlorella vulgaris, wastewater management, biomass, lipids, carbohydrates, proteins.

\section{Introduction}

There is a plentiful supply of fossil fuels at a reasonably low cost, but a rising use of fossil fuels is unlikely to be sustainable in the longer term principally due to the attributed increase in greenhouse gas (GHG) emissions from using these fuels and the environmental impact of these emissions on global warming (Hill et al. 2006; Pittman et al. 2011). The potential of microalgae as a source of lipids, proteins and carbohydrates has received considerable interest. The growth and photosynthetic activity of algae have been extensively studied under different environmental conditions over the last few decades (Burlew 1953; Moraine et al. 1979; Soeder et al. 1985; Cromar et al. 1996; Torzillo et al. 2003; Park, Craggs 2010; Zheng et al. 2013). For sustainability and economic viability, production optimization of mass culture conditions is needed. The growth of microalgae is faster than other photosynthetic plants, which indicates a high productivity per area. Microalgae can generally double their biomass within $24 \mathrm{~h}$, and the lipid content in several microalgae species exceed over
$30-80 \%$ of the dry biomass weight (Chisti 2007; Cho et al. 2011; Pittman et al. 2011). However, there remains a major price gap between microalgae-derived biofuels and fossil fuels despite the tremendous efforts to reduce the costs of algae production and processing (Pittman et al. 2011).

Wastewater derived from municipal water treatment plants can provide a low cost and sustainable means to grow algae for biofuels. The municipal wastewater stream from primary and secondary settling tanks is rich in nutrients including phosphorus, ammonia and organic nitrogen (Zhou et al. 2011). In addition, algae could be used in the aerobic treatment of waste in the secondary treatment process and in the removal of nitrogen and phosphorus from the wastewater (Hameed, Ebrahim 2007).

Green algae are one of the most used algae in wastewater treatment experiments and pilot plants for algae cultivation (Hameed, Ebrahim 2007). Different studies have shown that Chlorella vulgaris is capable of treating various wastewaters including textile wastewater (Lim et al. 2010; Chu et al. 2009), piggery wastewaters (Godos et al.

Corresponding author: Petras Venckus

E-mail: petras.venckus@gf.vu.lt 
2009; Ji et al. 2013), industrial effluent (Valderrama et al. 2002) and municipal wastewater (Cho et al. 2011; Zhou et al. 2011). Research on strain differences and the methods to acclimate strains to the wastewater environment are limited. In order to effectively couple the wastewater treatment with algae cultivation in the northern climate, selection and establishment of an adequate microalgae pool from local habitats becomes particularly important and necessary (Zhou et al. 2011). There are some limiting factors for wastewater usage as the source of microalgae cultivation media. A proper pre-treatment method to remove algae-feeding microorganisms and microorganisms competing for nutrient should be applied to increase algae biomass production (Cho et al. 2011). However, comparatively little effort is being conducted in northern regions due to strong seasonal effects on climate and solar insolation levels, which are likely to negatively affect feasibility and production costs. However, these disadvantages can be potentially mitigated by careful selection of strains that can be grown in wastewater at lower temperatures (Park et al. 2015).

The aim of this study is to investigate and establish mathematical models describing the rate of C. vulgaris biomass growth and accumulation of lipids, proteins and carbohydrates in biomass in dependence on total nitrogen and phosphorus concentration in wastewater and efficiency of removal these nutrient.

\section{Materials and methods}

Microalgae Chlorella vulgaris, in combination with the bacteria Flavimonas oryzihabitans was investigated in the present study. Flavimonas oryzihabitans (previously known as Pseudomonas oryzihabitans) is a gram-negative organism that survives in moist environments. There are a few studies that show the existence of interactions between microalgae and bacteria (Fukami et al. 1997; Krustok et al. 2015a; Krustok et al. 2015b). These studies postulate that the bacteria encourage microalgae growth due to the production of various growth factors, and that the microalgae produce simultaneously organic substances that encourage bacterial growth (Verschuere et al. 2000;
Riquelme, Avendaño-Herrera 2003; Krustok et al. 2015a, 2015b). Microalgae was cultivated in wastewaters taken from Vilnius City Municipal Wastewater Treatment Plant. Wastewater samples were taken at two different treatment stages: after mechanical treatment (after sedimentation of solid particles) and biological treatment, on 30/06/2011. The concentration of nitrates $\left(\mathrm{NO}_{3}^{-}\right)$, ammonium $\left(\mathrm{NH}_{4}^{-}\right)$, total nitrogen $(\mathrm{TN})$, phosphates $\left(\mathrm{PO}_{4}^{2-}\right)$, and total phosphorus (TP) on wastewater was determined at the JointStock Company "Vilniaus Vandenys" laboratory. Several dilutions of wastewater (2-20 times) in order to get the maximum effect for the algae biomass growth and quality conducted (Table 1). Samples of wastewater were autoclaved $30 \mathrm{~min}$ at $120^{\circ} \mathrm{C}$ to avoid contamination of other algae or bacteria. Distilled water was used for wastewater dilutions. The volume of one sample was $165 \mathrm{~mL}(150 \mathrm{~mL}$ of wastewater (diluted or not diluted) and $15 \mathrm{ml}$ of algae culture which was maintained in Basal media). Flasks were kept in daylight at room temperature $\left(21-24^{\circ} \mathrm{C}\right)$ for 19 days. Flasks were mixed once a day before measurements of biomass concentration. The optical density of cultures was determined with a spectrophotometer at a wavelength of $680 \mathrm{~nm}$. To estimate algal concentration standard routines include direct cell counts, absorbance or turbidity and chlorophyll content measurement. Typically $680 \mathrm{~nm}$ is associated with chlorophyll absorption. Rodrigues and co-authors published that when spectrophotometrical absorbance is the chosen method, a reading wavelength of $680 \mathrm{~nm}$ and $687 \mathrm{~nm}$ have also been used (Rodrigues et al. 2011). Analyses were performed in triplicate and then means were calculated. After 19 days of growth the algal biomass was centrifuged, frozen, lyophilized and used for the determination of the biomass biochemical composition. The supernatant in every flask was analyzed by the Joint-Stock Company "Vilniaus Vandenys" laboratory for determination of chemical composition. The LAND 58:2003, LAND 84:2006 and LAND 38:2000 were used to measure total phosphorus, total nitrogen and ammonium nitrogen, respectively.

The biochemical composition of Chlorella vulgaris (in combination with the bacteria Flavimonas oryzihabitans)

Table 1. Chemical composition of Vilnius City municipal wastewaters of different clarification stages used in the experiment

\begin{tabular}{|c|c|c|c|c|c|c|c|}
\hline \multirow[b]{2}{*}{$\begin{array}{l}\text { Wastewater } \\
\text { sample type }\end{array}$} & \multirow{2}{*}{$\begin{array}{c}\text { Percentage of raw } \\
\text { wastewater in the media }\end{array}$} & \multicolumn{6}{|c|}{ Parameter } \\
\hline & & $\mathrm{BOD} / \mathrm{COD}$ & $\begin{array}{c}\mathrm{TN} \\
\mathrm{mg} \mathrm{N} \mathrm{L}^{-1}\end{array}$ & $\begin{array}{l}\mathrm{NO}_{3}^{-}, \\
\mathrm{mg} \mathrm{L}^{-1}\end{array}$ & $\begin{array}{l}\mathrm{NH}_{4}^{-} \\
\mathrm{mg} \mathrm{L}^{-1}\end{array}$ & $\begin{array}{c}\mathrm{TP} \\
\mathrm{mg} \mathrm{P} \mathrm{L}^{-1}\end{array}$ & $\begin{array}{l}\mathrm{PO}_{4}{ }^{2-} \\
\mathrm{mg} \mathrm{L}^{-1}\end{array}$ \\
\hline $\begin{array}{l}\text { After } \\
\text { mechanical } \\
\text { treatment }\end{array}$ & 100\% (Undiluted) & $312 / 455$ & 85 & 0.26 & 34.5 & 8.37 & 7.28 \\
\hline $\begin{array}{l}\text { After } \\
\text { biological } \\
\text { treatment }\end{array}$ & 100\% (Undiluted) & $11 / 55$ & 35 & 0.21 & 29.1 & 0.14 & 0.062 \\
\hline
\end{tabular}


biomass was determined at the laboratory of the Institute of Ecosystem Study (Florence, Italy). The total carbohydrate content of the biomass was checked using the phenol-sulphuric acid method (Dubois et al. 1956). The total protein content was determined using Lowry's method (Lowry et al. 1951). The total lipid content was determined spectrophotometrically (Blight, Dyer 1959) after carbonization of the material was extracted with a 2:1 methanol/chloroform solution (Marsh, Weinstein 1966). Glyceryl tripalmitate (tripalmitin) (Sigma-Aldrich, Milan, Italy) was used as a standard for lipid extraction (Holland, Gabbott 1971). Analyses were performed in triplicate. All data presented in $\mathrm{mg}$ of compound (lipids, proteins, carbohydrates) in $1 \mathrm{~g}$ of dry algae biomass ( $\mathrm{mg} \mathrm{g}^{-1} \mathrm{~d}$. wt.).

For statistical analysis multiple linear regressions (Quinn, Keough 2002) were used. Analyses were conducted with Microsoft Excel 2013 data analysis tool pack (Microsoft. Microsoft Excel. Redmond, Washington: Microsoft, 2013. Computer Software). The significance level $(\alpha)$ is 0.05 .

\section{Results and discussion}

\subsection{Consumption of nitrogen and phosphorus}

Algae cells can absorb nitrogen and phosphorus from culture medium (Georgianna, Mayfield 2012). Nutrient ( $\mathrm{N}$ and $\mathrm{P}$ ) removal is directly linked to photosynthetic activity and in microalgae-based systems they are converted into algal biomass that can be sustainably recycled (Singh et al. 2011). In this experiment the initial N:P ratio in mechanically treated wastewater was 10:1 and in biologically treated - 10:0.04. It is known, that such ratio is suitable for photosynthetic microorganisms' cultivation (Lee et al. 2000; Vezie et al. 2002). Our results shows, that the highest consumption of total $\mathrm{N}$ and total $\mathrm{P}$ was observed in mechanically treated

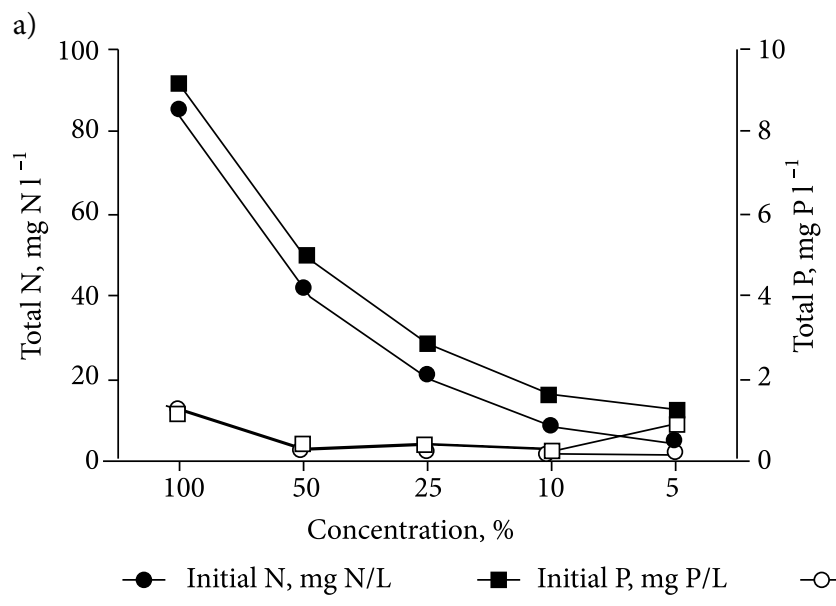

undiluted wastewater (73 $\mathrm{mg} \mathrm{N} \mathrm{L}^{-1}$ and 7,26 $\mathrm{mg} \mathrm{P} \mathrm{L}^{-1}$ ) (Fig. 1). By lowering the amount of $\mathrm{N}$ and $\mathrm{P}$ in wastewater the consumption of elements lowers too. Another study (Lau et al. 1996) showed that most of the nitrogen (>80\%) was removed in the five days of cultivation and most of the phosphorus was removed in one to two days of cultivation. Our experiment showed that during the 19 day cultivation period $87 \%$ of initial nitrogen and $86 \%$ of initial phosphorus was removed from the wastewater. Results of this study demonstrated that Chlorella vulgaris is capable of efficient nitrogen and phosphorus removal from wastewater. After the cultivation of C. vulgaris in the wastewater the nitrogen concentration lowers significantly, but never lowered below $1.4 \mathrm{mg} \mathrm{N} \mathrm{L}^{-1}$. Phosphorus was consumed too, but the concentration

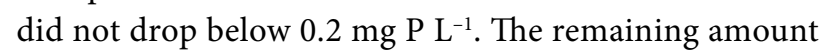
of nitrogen and phosphorus possibly have not been absorbed by algae due to physiological limitations of algae or chemical properties of compounds left in the wastewaters. Growing C. vulgaris in different diluted wastewater the amount of remaining nitrogen and phosphorus after cultivation was quite similar and varied from 1.4 to $3.4 \mathrm{mg} \mathrm{N} \mathrm{L}^{-1}$ and from 0.2 to $0.37 \mathrm{mg} \mathrm{P} \mathrm{L}^{-1}$ Exception was undiluted wastewater after mechanical treatment. The concentration of nitrogen and phosphors remaining after cultivation was $12.0 \mathrm{mg} \mathrm{N} \mathrm{L}^{-1}$ and $1.11 \mathrm{mg} \mathrm{P} \mathrm{L}^{-1}$. This phenomenon could be explained by the high concentrations of nutrients in the medium. In that case the limiting factors for algae growth could be not chemical but physical, for example light intensity or density of culture.

The significant increase of initial phosphorus concentrations in Figure $1 \mathrm{~B}$ compared to Table 1 is due to addition of phosphorus from phosphorus-rich growth media which was used preparing the inoculate of Chlorella vulgaris culture.

Fig. 1. Consumption of nitrogen and phosphorus by Chlorella vulgaris in different type and concentration of wastewaters of Vilnius city municipal wastewater treatment plant: (a) - after mechanical treatment; b) - after biological treatment). "\%" shows the percentage of raw wastewater in the culture medium. Note the different scales in each panel 


\subsection{Growth dynamics}

The growth rate of C. vulgaris was determined spectrophotometrically by measuring the optical density of the culture every day. During the first two days of cultivation a lag phase was observed in all cultures and in some cultures, optical density decreased on the second day (Fig. 2). It is known, that the changing environmental conditions could cause stress to algae cells and lead to a decrease of pigment content, especially chlorophyll (Boussiba et al. 1999). From the second to the fifth day an increase of growth rate was observed. From day five until the end of the experiment, growth stabilized and the growth rates of the cultures with different initial nitrogen and phosphorus concentrations began to differ. The highest growth rate $(+0.078$ and +0.076 OD per day) was measured in the culture with the highest amount of nitrogen and phosphorus. It were in the mechanically treated undiluted and double diluted wastewater. The lowest growth rate $(+0.041 \mathrm{OD}$ per day) was measured in the culture with the lowest amount of nitrogen (but not phosphorus). The lowest growth rate was in the mechanically treated wastewater that was diluted 20 times.

The best-fit trend line shows that the growth rate depends logarithmically on the amount of nitrogen from 4.25 to $85.0 \mathrm{mg} \mathrm{L}^{-1}$ (Fig. 3; Eq. (1)).

$$
y=0.0163 \ln (x)+0.0141 ; R^{2}=0.847,
$$

where: $y$ is the growth rate and $x$ is the concentration of nitrogen in the starting medium.

Equation (1) indicates that the growth rate is $85 \%$ determined by the concentration of nitrogen in the starting medium. Since this dependence is logarithmic, the addition of nitrogen has a lower impact to the growth rate as the concentration of nitrogen in the starting medium getting higher.

a)

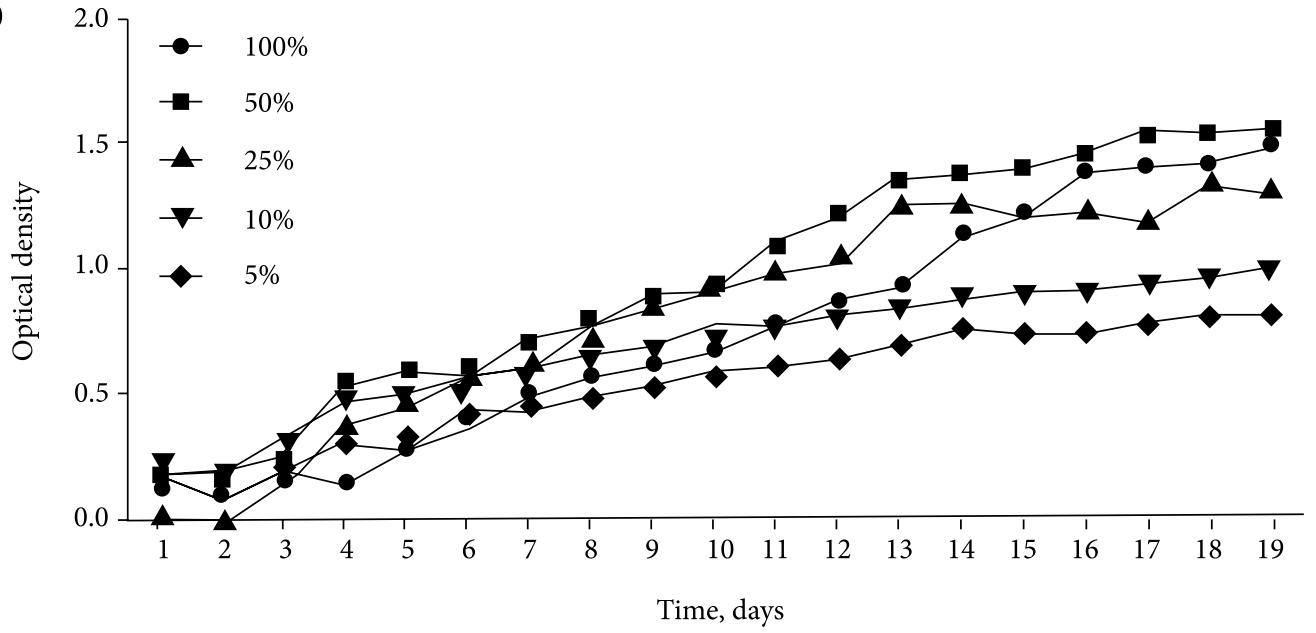

b)

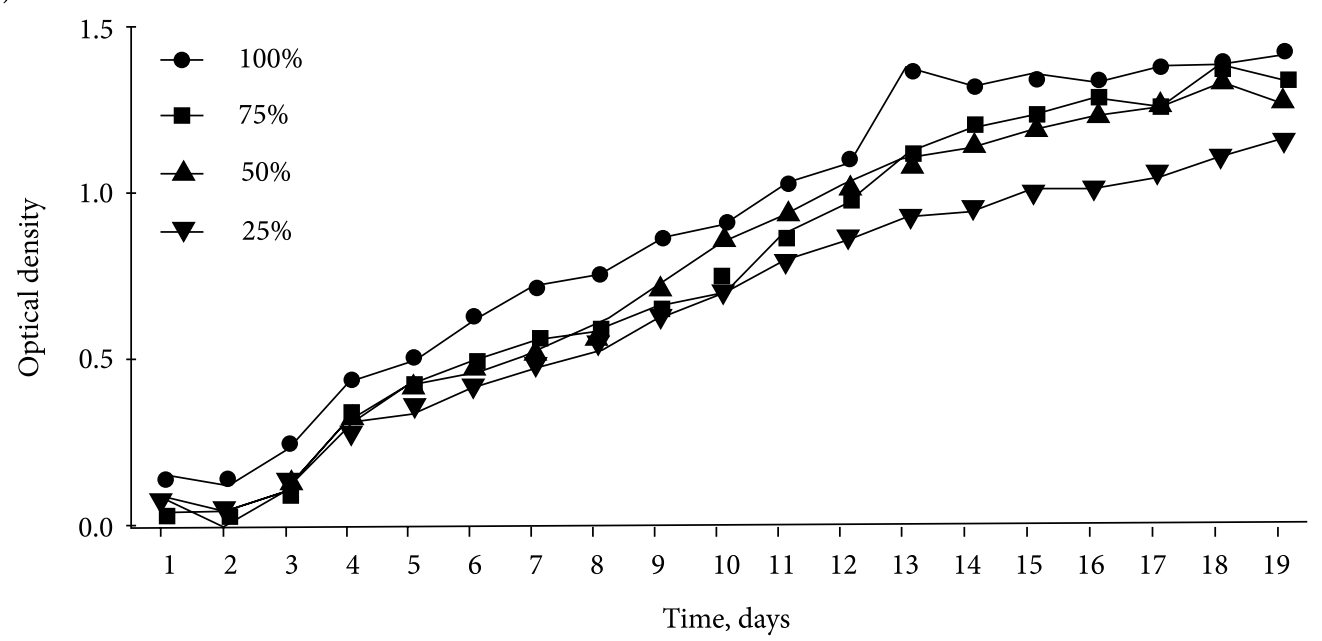

Fig. 2. Growth dynamics of Chlorella vulgaris (in combination with bacteria Flavimonas oryzihabitans) in different type and concentration of wastewater of Vilnius city municipal wastewater treatment plant (a) - wastewater after mechanical treatment; b) - wastewater after biological treatment). "\%" shows the percentage of raw sewage water in the medium 


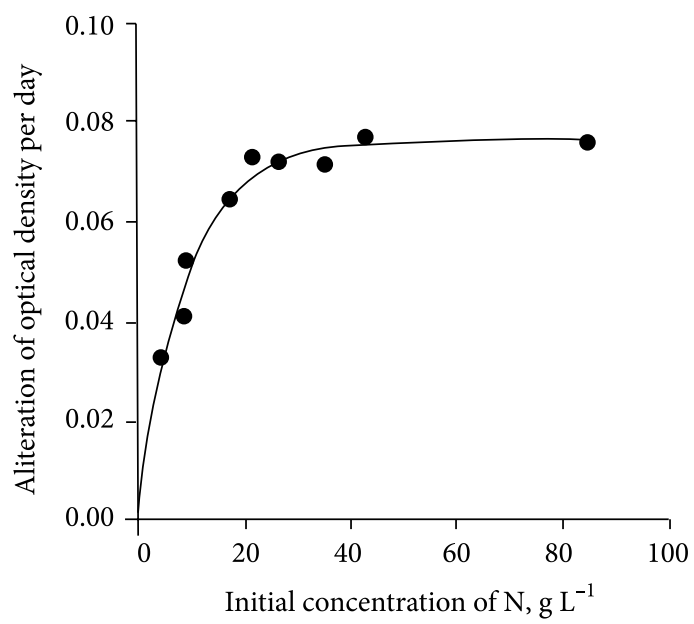

Fig. 3. Variation of the optical density with the initial nitrogen concentration

\subsection{Biochemical composition of the biomass}

There were obvious differences in biochemical composition in Chlorella vulgaris biomass treated under different conditions. It is known, that proteins comprise a large fraction of the biomass of actively growing microalgae and in certain species protein content can reach values as high as $50-60 \%$ by dry weight biomass (Gonzalez-Lopez et al. 2010). Our data shows that algae cultivated under nitrogen-rich conditions accumulated higher amounts of proteins and lower amounts of carbohydrates in their biomass. Lower initial concentrations of nitrogen led to a lower amount of proteins and higher amount of carbohydrates in the algae cells. The highest protein content (432 $\mathrm{mg} \mathrm{g}^{-1} \mathrm{~d}$. wt.) was detected in the biomass cultivated in undiluted mechanically treated wastewaters. The highest carbohydrate content $\left(577 \mathrm{mg} \mathrm{g}^{-1} \mathrm{~d}\right.$. wt.) was in the biomass cultivated in $10 \%$ mechanically treated wastewaters. A step wise multiple linear regression analysis was performed in order to predict the biochemical biomass composition under different initial concentrations of nitrogen and phosphorus in the medium. Lipids and carbohydrates represent the main energy storage molecules in algae. Nutrient stress has been the method for increasing lipid and starch accumulation in green algae and diatoms. Under nitrogen deplete conditions, some green algae accumulate high levels of lipids as triacylglycerols (TAG), (Hu et al. 2008). Tables 2 and 3 summarize the results of the multiple regression analysis in which the amounts of proteins and carbohydrates were calculated as a function of variables of initial nitrogen concentration and initial phosphorus concentration. A multiple regression model for protein analysis was modified using backward elimination of $\mathrm{P}$ from the initial model due to low significance of this variable $(p>0.05)$. A multiple linear regression model was unsuitable for describing the dependence of lipid content and the initial nitrogen and phosphorus concentrations in the medium (No significant $(\mathrm{p}<0.05)$ $\mathrm{R}^{2}$ value was found).

Table 2. Multiple linear regression for content of proteins prediction. Nine cases were included in the analysis

\begin{tabular}{lccccc}
\hline Source & df & $\begin{array}{c}\text { Sum of } \\
\text { squares }\end{array}$ & $\begin{array}{c}\text { Mean } \\
\text { square }\end{array}$ & F-ratio & $\begin{array}{c}\text { Significance } \\
\text { F }\end{array}$ \\
\hline Regression & 2 & 45900.82 & 22950.41 & 69.30 & $7,14 \mathrm{E}-05$ \\
\hline Residual & 6 & 1987.17 & 331.19 & & \\
\hline Total & 8 & 47888 & & & \\
\hline Variable & Coefficients & $\begin{array}{c}\text { Standard } \\
\text { Error }\end{array}$ & $\mathrm{t}$ & P-value \\
\hline Constant & 204,14 & 11,61 & 17,57 & $4,75 \mathrm{E}-07$ \\
\hline $\mathrm{N}$ & 2,98 & 0,32 & 9,32 & $3,38 \mathrm{E}-05$ \\
\hline
\end{tabular}

Note: Dependent variable was content of proteins. Independent variable was initial concentration of nitrogen $(N)$.

$$
C=204.139+2.983 N \text {, }
$$

where: $C$ - Content of proteins in the biomass $\left(\mathrm{mg} \mathrm{g}^{-1}\right.$ d.wt.), $N$ - initial concentration of nitrogen $\left(\mathrm{mg}^{1} \mathrm{~L}^{-1}\right)$.

Table 3. Multiple linear regression for content of carbohydrates prediction. Nine cases were included in the analysis

\begin{tabular}{lccccc}
\hline \multicolumn{1}{c}{ Source } & df & $\begin{array}{c}\text { Sum of } \\
\text { squares }\end{array}$ & $\begin{array}{c}\text { Mean } \\
\text { square }\end{array}$ & F-ratio & $\begin{array}{c}\text { Signifi- } \\
\text { cance F }\end{array}$ \\
\hline Regression & 2 & 134579.37 & 67289.68 & 490.26 & $2.024 \mathrm{E}-07$ \\
\hline Residual & 6 & 823.51 & 137.25 & & \\
\hline Total & 8 & 135402.88 & & & \\
\hline \hline Variable & Coefficients & $\begin{array}{c}\text { Standard } \\
\text { Error }\end{array}$ & $\mathrm{t}$ & p-value \\
\hline Constant & 604.16 & 6.83 & 88.45 & $1.40 \mathrm{E}-10$ \\
\hline $\mathrm{N}$ & -6.81 & 0.36 & 18.46 & $1.62 \mathrm{E}-06$ \\
\hline $\mathrm{P}$ & 16.66 & 3.26 & 5.10 & $2.21 \mathrm{E}-03$ \\
\hline
\end{tabular}

Note: Dependent variable was content of carbohydrates. Independent variables were initial concentration of nitrogen $(\mathrm{N})$ and initial concentration of phosphorus $(\mathrm{P})$.

$$
C=604.16+(-6.81 N)+(16.66 P),
$$

where: $C$ - Content of carbohydrates in the biomass ( $\mathrm{mg} \mathrm{g}^{-1}$ d.wt.), $N$ - initial concentration of nitrogen (mg N L $\mathrm{N}^{-1}$ ), $P$ - initial concentration of phosphorus (mg P L $\left.\mathrm{L}^{-1}\right)$.

Figure 4 and the regression analysis (Tables $2-3$ and Equations 2-3) show that the initial concentration of nitrogen has a significant influence over the biochemical composition of algae biomass. A higher concentration of initial nitrogen concentration leads to the accumulation of proteins in the biomass (Fig. $4 \mathrm{~A}$ ); however, a shortage of both nitrogen and phosphorus leads to the accumulation of carbohydrates (Fig. 4 A, B). Mutlu et al. (2011) described this dependence too, but they noticed 

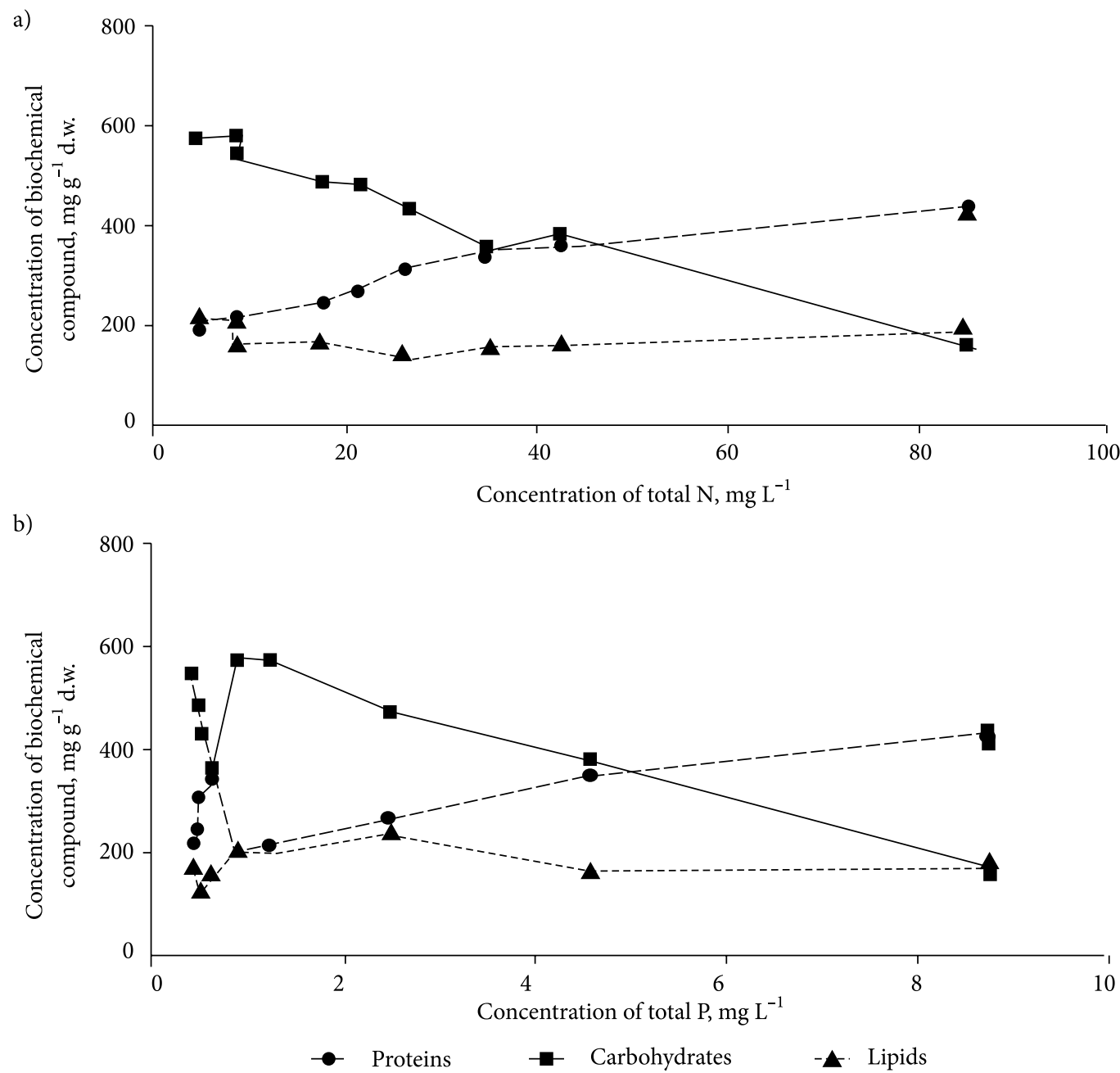

Fig. 4. Dependence of concentration of lipids, proteins and carbohydrates in Chlorella vulgaris (grown with bacteria Flavimonas oryzihabitans) biomass after cultivation period in different initial concentration of total nitrogen (a) and total phosphorus (a) in cultivation media

the accumulation of lipids due to the shortage of nitrogen. However Rodolfi et al. (2009) observed an increase in both lipid content and areal lipid productivity through nutrient starvation. Several authors (Perez-Garcia et al. 2011) have proposed that lipid accumulation may not be dependent on nitrogen starvation but on excess carbon in the culture medium. In our study no significant correlation between concentration of nitrogen (Fig. 4a) or phosphorus (Fig. 4b) in the initial media and the content of lipids in the biomass was observed.

\section{Conclusions}

Chlorella vulgaris is capable of efficient nutrient (nitrogen and phosphorus) removal from Vilnius City wastewater. During the experiment $87 \%$ to $93 \%$ of total nitrogen and up to $87 \%$ of total phosphorus were removed from the municipal wastewaters of Vilnius City. The growth rate and the concentration of proteins in the C. vulgaris biomass are directly dependent on the starting concentration of nitrogen in the medium. The highest growth rate and the concentration of proteins ( $432 \mathrm{mg} \mathrm{g}^{-1}$ ) were reached in the wastewater with the concentration of total nitrogen in the medium from 42.5 to $85.0 \mathrm{mg} \mathrm{N} \mathrm{L}^{-1}$. The lower concentration of total nitrogen and the higher concentration of total phosphorus lead to a higher concentration of carbohydrates in the biomass of $C$. vulgaris. The highest concentration of carbohydrates in the biomass $\left(577 \mathrm{mg} \mathrm{g}^{-1}\right.$ ) was reached by cultivating C. vulgaris in the medium containing $4.0 \mathrm{mg} \mathrm{N} \mathrm{L}^{-1}$ and $0.4 \mathrm{mg} \mathrm{P} \mathrm{L}^{-1}$. The remediation of wastewater using C. vulgaris provides an environmentally acceptable and effective option for wastewater remediation, which not only recycles valuable nutrients but also improves water quality. Therefore C. vulgaris may be regarded as efficient nutrient remover.

\section{Acknowledgements}

We are grateful for the dr. Pietro Carlozzi research group for the possibilities to make biochemical analyses of the Chlorella vulgaris biomass. 


\section{References}

Blight, E. G.; Dyer, W. J. 1959. A rapid method of total lipid extraction and purification, Canadian Journal of Biochemistry and Physiology 37(8): 911-917.

https://doi.org/10.1139/o59-099

Boussiba, S.; Bing, W.; Yuan, J. P.; Zarka1, A.; Chen, F. 1999. Changes in pigments profile in the green alga Haeamtococcus pluvialis exposed to environmental stresses, Biotechnology Letters 21(7): 601-604. https://doi.org/10.1023/A:1005507514694

Burlew, J. S. 1953. Algae culture: from laboratory to pilot plant. Carnegie Institution of Washington, Washington DC.

Chisti, Y. 2007. Biodiesel from microalgae, Biotechnology Advances 25(3): 294-306.

https://doi.org/10.1016/j.biotechadv.2007.02.001

Cho, S.; Luong, T. T.; Lee, D; Oh, Y.; Lee, T. 2011. Reuse of effluent water from a municipal wastewater treatment plant in microalgae cultivation for biofuel production, Bioresource Technology 102(18): 8639-8645.

https://doi.org/10.1016/j.biortech.2011.03.037

Chu, W. L.; See, Y. C.; Phang, S. M. 2009. Use of immobilised Chlorella vulgaris for the removal of colour from textile dyes, Journal of Applied Phycology 21: 641-648. https://doi.org/10.1007/s10811-008-9396-3

Cromar, N. J.; Fallowfield, H. J.; Martin, N. J. 1996. Influence of environmental parameters on biomass production and nutrient removal in a high rate algal pond operated by continuous culture, Water Science and Technology 34(11): 133-140. https://doi.org/10.1016/S0273-1223(96)00830-X

Dubois, M.; Gilles, K. A.; Hamilton, J. K.; Rebers, P. A.; Smith, F. 1956. Colorimetric method for determination of sugars and related substances, Analalytical Chemistry 28(3): 350-356. https://doi.org/10.1021/ac60111a017

Fukami, K.; Nishijima, T.; Ishida, Y. 1997. Stimulative and inhibitory effects of bacteria on the growth of microalgae, Hydrobiologia 358: 185-191. https://doi.org/10.1023/A:1003139402315

Georgianna, D. R.; Mayfield, S. P. 2012. Exploiting diversity and synthetic biology for the production of algal biofuels, Nature 488: 329-335. https://doi.org/10.1038/nature11479

Godos, E.; Blanco, S.; Garcia-Encina, P. A.; Becares, E.; Munoz, R. 2009. Long-term operation of high rate algal ponds for the bioremediation of piggery wastewaters at high loading rates, Bioresource Technology 100: 4332-4339.

https://doi.org/10.1016/j.biortech.2009.04.016

Gonzalez-Lopez, C.V.; Ceron-Garcia, M. C.; Acien-Fernandez, F. G.; Segovia-Bustos, C.; Chisti, Y.; Fernandez-Sevilla, J. M. 2010. Protein measurements of microalgal and cyanobacterial biomass, Bioresource Technology 101(19): 7587-7591. https://doi.org/10.1016/j.biortech.2010.04.077

Hameed, M. S. A.; Ebrahim, O. H. 2007. Biotechnological potential uses of immobilized algae, International Journal of Agriculture and Biology 9(1): 183-192.

Hill, J.; Nelson, E.; Tilman, D.; Polasky, Tiffany, D. 2006. Environmental, economic, and energetic costs and benefits of biodiesel and ethanol biofuels, Proceedings of the Nation Academy of Science of the United States of America 103(30): 11210-11210. https://doi.org/10.1073/pnas.0604600103

Holland, D.; Gabbott, P. 1971. A micro - analytical scheme for determination of protein, carbohydrate, lipid and RNA levels in marine invertebrate larvae, Journal of the Marine Biological Association of the UK 59(1): 95-101.

https://doi.org/10.1017/S0025315400015034

Hu, Q.; Sommerfeld, M.; Jarvis, E.; Ghirardi, M.; Posewitz, M.; Seibert, M.; Darzins, A. 2008. Microalgal triacylglycerols as feedstocks for biofuel production: perspectives and advances, Plant Journal 54(4): 621-639.

https://doi.org/10.1111/j.1365-313X.2008.03492.x

Ji, M.; Kim, H.; Sapireddy, V. R.; Yun, H.; Abou-Shanab, R. A. I.; Choi, J.; Lee, W.; Timmes, T. C.; Inamuddin, J. B. 2013. Simultaneous nutrient removal and lipid production from pretreated piggery wastewater by Chlorella vulgaris YSW-04, Applied Microbiology and Biotechnology 97(6): 2701-2710. https://doi.org/10.1007/s00253-012-4097-x

Krustok, I.; Truu, J.; Odlare, M.; Truu, M.; Ligi, T.; Tiirik, K.; Nehrenheim, E. 2015b. Effect of lake water on algal biomass and microbial community structure in municipal wastewater-based lab-scale photobioreactors, Applied Microbiology and Biotechnology 99(15): 6537-6549.

https://doi.org/10.1007/s00253-015-6580-7

Krustok, I.; Odlare, M.; Shabiimam, M. A.; Truu, J.; Truu, M.; Ligi, T.; Nehrenheim, E. 2015a. Characterization of algal and microbial community growth in a wastewater treating batch photo-bioreactor inoculated with a lake water, Algal Research 11: 421-427. https://doi.org/10.1016/j.algal.2015.02.005

LAND 38:2000. Vandens kokybe. Amonio kiekio nustatymas. Rankinis spektrotometrinis metodas [Water quality - determination of ammonia - Manual spectrofotometrical method]. Lithuanian standard.

LAND 58:2003. Vandens kokybè. Fosforo nustatymas [Water quality - Determination of phosphorus]. Lithuanian standard.

LAND 84:2006. Vandens kokybe. Kjeldalio azoto nustatymas. Mineralizavimo selenu metodas [Water quality - Determination of Kjeldahl nitrogen - Selenium mineralization method]. Lithuanian standard.

Lau, P. S.; Tam, N. F. Y.; Wong, Y. S. 1996. Wastewater nutrients removal by Chlorella vulgaris: Optimization through acclimation, Environmental Technology 17(2): 183-189. https://doi.org/10.1080/09593331708616375

Lee, S. J.; Jang, M. H.; Kim, H. S.; Yoon, B. D.; Oh, H. M. 2000. Variation of microcystin content of Microcystis aeruginosa relative to medium N:P ration and growth stage, Journal of Applied Microbiology 89: 323-329.

https://doi.org/10.1046/j.1365-2672.2000.01112.x

Lim, S. L.; Chu, W. L.; Phang, S. M. 2010. Use of Chlorella vulgaris for bioremediation of textile wastewater, Bioresource Technology 101(19): 7314-7322. https://doi.org/10.1016/j.biortech.2010.04.092

Lowry, O. H.; Rosebrough, N. J.; Farra, L.; Randall, R. J. 1951. Protein measurement with the Folin's phenol reagent, Journal of Biological Chemistry 193(1): 263-275.

Marsh, J.; Weinstein, D. 1966. Simple charring method of determination of lipids, Journal of Lipid Research 7: 574-576.

Moraine, R.; Shelef, G.; Meydan, A.; Levi, A. 1979. Algal single cell protein from wastewater treatment and renovation process, Biotechnology and Bioengeneering 21: 1191-1207. https://doi.org/10.1002/bit.260210709

Mutlu, Y. B.; Isik, O.; Uslu, L.; Koc, K.;. Durmaz, Y. 2011. The effects of nitrogen and phosphorus deficiencies and nitrite addition on the lipid content of Chlorella vulgaris 
(Chlorophyceae), African Journal of Biotechnology 10: 453456.

Park, J. B. K.; Craggs, R. J. 2010. Wastewater treatment and algal production in high rate algal ponds with carbon dioxide addition, Water Science and Technology 61(3): 633-639. https://doi.org/10.2166/wst.2010.951

Park, K. C.; Whitney, C. E. G.; Kozera, C.; O’Leary, S. J. B.; McGinn, P. J. 2015. Seasonal isolation of microalgae from municipal wastewater for remediation and biofuel applications, Journal of Applied Microbiology 119(1): 76-87. https://doi.org/10.1111/jam.12818

Perez-Garcia, O.; Escalante, F. M. E.; de-Bashan, L. E.; Bashan, Y. 2011. Heterotrophic cultures of microalgae: metabolism and potential products, Water Research 45(1): 11-36. https://doi.org/10.1016/j.watres.2010.08.037

Pittman, J. K.; Dean, A. P.; Osundeko, O. 2011. The potential of sustainable algal biofuel production using wastewater resources, Bioresource Technology 102(1): 17-25. https://doi.org/10.1016/j.biortech.2010.06.035

Quinn, G.; Keough, M. 2002. Experimental design and data analysis for biologists. Cambridge University Press. https://doi.org/10.1017/CBO9780511806384

Riquelme, C. E.; Avendaño-Herrera, R. E. 2003. Microalgae and bacteria interaction in the aquatic environment and their potential use in aquaculture, Revista Chilena de Historia Natural 76(1): 725-736.

Rodolfi, L.; Zitelli, G. C.; Bassi, N.; Padovani, G.; Biondi, N.; Bonini, G.; Tredici, M. R. 2009. Microalgae for oil: strain selection, induction of lipid synthesis and outdoor mass cultivation in a low-cost photobioreactor, Biotechnology and Bioengineering 102(1): 100-112.

https://doi.org/10.1002/bit.22033

Rodrigues, L. R.; Arenzon, A.; Raya-Rodriguez, M. T.; Fontoura, N. F. 2011. Algal density assessed by spectrophotometry: a calibration curve for the unicellular algae Pseudokirchneriella subcapitata, Journal of Environmental Chemistry and Ecotoxicology 3(8): 225-228.

Singh, M.; Reynolds, D. L.; Das, K. C. 2011. Microalgal system for treatment of effluent from poultry litter anaerobic digestion, Bioresource Technology 102(23): 10841-10848. https://doi.org/10.1016/j.biortech.2011.09.037

Soeder, C. J.; Hegewald, E.; Fiolitakis, E.; Grobbelaar, J. U. 1985. Temperature dependence of population growth in a green microalga: thermodynamic characteristics of growth intensity and the influence of cell concentration, Zeitschrift Natur 40: $227-233$.

Torzillo, G.; Goksan, T.; Faraloni, C.; Kopecky J.; Masojidek J. 2003. Interplay between photochemical activities and pigment composition in an outdoor culture of Haematococcus pluvialis during the shift from the green to red stage, Journal of Applied Phycology 15: 127-136. https://doi.org/10.1023/A:1023854904163

Valderrama, L. T.; Del Campo, C. M.; Rodriguez, C. M.; Bashan, L. E.; Bashan, Y. 2002. Treatment of recalcitrant wastewater from ethanol and citric acid production using the microalga Chlorella vulgaris and the macrophyte Lemna minuscula, Water Research 36(17): 4155-4192. https://doi.org/10.1016/S0043-1354(02)00143-4

Verschuere, L.; Rombaut, G.; Sorgeloos, P.; Verstraete, W. 2000. Probiotic bacteria as biological control agents in aquaculture, Microbiology and Molecular Biology Reviews 64(4): 655-671. https://doi.org/10.1128/MMBR.64.4.655-671.2000

Vezie, C.; Rapala, J.; Vaitomaa, J.; Seitsonen, J.; Sivonen, K. 2002. Effect of nitrogen and phosphorus on growth of toxic and nontoxic Microcystis strains and on intracelular microcystin concentrations, Microbial Ecology 43(1): 443-454. https://doi.org/10.1007/s00248-001-0041-9

Zheng, Y.; Li, T.; Yu, X.; Bates, P. D.; Dong, T.; Chen, S. 2013. High-density fed-batch culture of a thermo tolerant microalga Chlorella sorokiniana for biofuel production, Applied Energy 108: 281-287. https://doi.org/10.1016/j.apenergy.2013.02.059

Zhou, W.; Li, Y.; Min, M.; Hu, B.; Chen, P.; Ruan, R. 2011. Local bioprospecting for high-lipid producing microalgal strains to be grown on concentrated municipal wastewater for biofuel production, Bioresource Technology 102(13): 6909-6919. https://doi.org/10.1016/j.biortech.2011.04.038

Petras VENCKUS. PhD student (biology). Lecturer at Department of Botany and Genetics, Vilnius University (VU). Research interests: algae biotechnology, wastewater treatment, various high value biochemical compounds obtained from algae, development of technologies to optimise the growth of algae for renewable fuels.

Jolanta KOSTKEVIČIENĖ. Dr. Assistant Professor, Vilnius University (VU). Doctor of Biomedical Sciences, Vilnius University (VU), 2001. Publications: author of 2 textbooks, over 20 research papers. Scientific supervisor of research work at $\mathrm{PhD}, \mathrm{B}$. Sc., and M. Sc. levels. Research interest: algae taxonomy, biology, ecology, and biotechnology (optimization of algae cultivation for the biomass rich in different bioactive compounds; treatment of different type of wastewater).

Vida BENDIKIENĖ. Dr, Habilitation Procedure (HP), Chief Research Fellow of Department Biochemistry and Molecular Biology, Vilnius University (VU). Doctor of Science Habilitation Procedure (biochemistry), VU, 2008. Doctor of Science (biochemistry), Byelorussian State University (Minsk, Byelorussia), 1980. Publications: author of 1 study-guide, 1 patent, over 40 research papers and 12 inventions. Scientific supervisor of $\mathrm{PhD}$ projects and diploma projects of BSc and MSc levels. Research interests: biotechnology, applied enzymology, enzymes-catalyzed biotechnologically important processes optimization methods; development of technologies to optimize the growth of algae for renewable fuels, specialty chemicals and value-added chemical compounds. 